International Journal of English Literature and Social Sciences
Vol-7, Issue-1; Jan-Feb, 2022
Journal Home Page Available: https://ijels.com/
Journal DOI: $10.22161 /$ ijels

Peer-Reviewed Journal

\title{
Blinding Power and Awakened Morality: A Study of Arthur Koestler's Darkness at Noon
}

\author{
Dr. Shivangi Chanyal ${ }^{1}$, Ruchita Bhatt ${ }^{2}$ \\ ${ }^{1}$ Assistant Professor, DSB Campus, Kumaon University, Nainital, India \\ ${ }^{2}$ Assistant Professor, Govt. P.G. College, Champawat, India
}

Received: 16 Dec 2021; Received in revised form: 15 Feb 2022; Accepted: 22 Feb 2022; Available online: 28 Feb 2022 (C)2022 The Author(s). Published by Infogain Publication. This is an open access article under the CC BY license (https://creativecommons.org/licenses/by/4.0/).

\begin{abstract}
Power either can elevate ethically or corrupt morally. It is intertwined with a few curses; fundamentally it is cursed to bring moral hypocrisy with it. Power,especially power over human beings, inevitably corrupts. Judging by the normal expression of humanity, there is nothing more important in the life of a human being or a nation than the moral standards, by which life is governed and the same perception infers that in all set of conditions, the righteous approach to conduct oneself towards human beings, is to treat with compassion. But a totalitarian state defies all morality and puts everything at stake in blind pursuit of power. Arthur Koestler in his Darkness at Noon gives us a guided tour of totalitarianism, his novel is concentrated on acute criticism of Stalin's power-hungry rule, a totalitarian ruler of Soviet Russia. Koestler, who was influenced by Sigmund Freud, intricately acquaints the readers with the inner workings of a totalitarian party through the psychological happenings in the mind of his protagonist Rubashov. Rubashov who is a communist militant, a devote party official, manifested imprisoned for unexplained crime at the beginning of the novel. It's while he awaits his execution in his cell that he begins to have the most serious doubts about the objective morality of the party. The present paper studies the aforementioned novel to explore the relation between power and morality and the role of consciousness, to help the protagonist to realise the importance of morality in life. It further examines the need to implicate morality in the power structure to maintain its legitimacy.
\end{abstract}

Keywords-Totalitarianism, Stalinism, Great purge, Utopia, Bolshevik, Machiavelli, Sigmund Freud. Dostoevsky. Marxism.

\section{INTRODUCTION}

Though Power and morality look like two sides of a coin but they are not, we can't make a sole choice between the two. It can't be either head or tales. This relation between power and morality is more like a Rubik's cube where it is desired to get all the smaller pieces right in order to solve the puzzle. The same very idea that a ruler can't make a sole choice between power and morality is reflected through Koestler's choice of epigraphs in his masterpiece Darkness at Noon. The novel has two epigraphs. One of them has been taken from the Machiavelli's Discorsi which states"He who establishes a dictatorship and does not kill Brutus, or he who founds a republic and does not kill sons of Brutus,will only reign a short time". Machiavelli was a great Italian renaissance diplomat, writer, and philosopher. He wrote the book Discorsi, which is quite puzzling in nature. The book emphasizes the necessity of brutality in power structure and maintenance that in order to gain and remain in power one has to resort to killing and other grim methods and goes on to explain such necessity. The other epigraph of Darkness at Noon comes from the book of a very popular Russian writer named Fyodor Dostoevsky' sliterary classic Crime and Punishment. Dostoevsky's novel is based on the theme of mental anguish and moral dilemma of its protagonist Rodion Raskolnikov, who formulates a plan to kill an unscrupulous pawn braker for her money. The epigraph which reads, "Man, man one cannot quite live 
without pity" appears to point the necessity of mercy in human lives. By placing two contradictory epigraphs in the novel Koestler made it abundantly clear that though some deviations from the path of mercy can be accepted in order to rule efficiently even so the appeal to morality is necessary if human action is not to be brutalised and human dignity is to be maintained.

History tells that equation between power and morality is that of inclusivity not of exclusivity. As stated by T. P. Chia, "power without morality is a dehumanising weapon". First fifty years of the $20^{\text {th }}$ century corroborate this dehumanisation. Millions of deaths caused by two massive world wars, the Russian Revolution leading to distorted socialism, extreme nationalism of Nazis and fascists resulting into ethnic holocaust and their ideologies resulting into mass persecution put the question mark on the very face of humanity.Arthur Koestler's Darkness at Noon documents one such horrific event from the tumultuous twentieth century times. It presents the history of Soviet Russia in 1940s, though Koestler does not identify the country but the names of the characters and political system indicates Russian. The book is based on Moscow show trials of 1936 in which more than half of old revolutionaries of Russian revolution were charged with treason consequently tried and hanged.Koestler explains the riddle of these trials with persuasive simplicity in the book.

1930's was the decade when Joseph Stalin was trying to consolidate his power and took extreme measures to eliminate any possible chances of rivalry. $\mathrm{He}$, in order to secure his position as party commander conspired, expelled and where necessary liquidated prominent Bolshevik leaders of the party, who he feared would challenge his authority. He was distinctly hostile to thoserivals who were politically and intellectually superior to him. He fabricated charges of disloyalty against them, used physical torture and psychological unrest methods to extract fake confessions from themand ultimately liquidated them either administratively or publicly. Most of the people who were executed in these show trials were the pioneer of Russian revolution.

The entire world was startled by the news of execution of these old revolutionaries. Rubashov, the protagonist of Koestler's magnum opus Darkness at Noon, collectively stands for as Koestler puts it 'a number of men who were victims of Moscow show trials.'Many of these victims were personally known tothe author. Koestler himself had a taste of political prison when he was imprisoned during Spanish civil war. He had beena loyal member of the communist party but abandoned it after he was released from his solitary confinement in 1938. Being aninsider of the party, he had the opportunity to closely observe the working ethics of a totalitarian government and with the understanding of their tainted tactics came an increasing sense of discomfort. He began to harbour serious concern for political atrocities carried on by Stalin's government. Many of the old Bolshevik were also discouraged by Stalin's regime of terror and aggressive methods employed by him. They,in the past,joined the party after being magnetised by Marxism- Leninism and their utopian goals of creating socialist- stateless society. They worked religiously under Lenin's leadership to make Soviet Russia a better place where everyone was equal but soonthese elysian goals were led astray as Lenin abandoned the notion of gradual growth to score supposed targets quickly and embraced the strategy of abrupt changes that led to violence on a mass scale. After Lenin's death, Stalin securedthe party's command by political intriguing and Leninism led to Stalinism. Stalin after holding the position of top-notch inside the party begin to suspect the loyalty of these devoted Leninists. In order to exercise sovereign authority, he has always desired, he started abolishing anyone and everyone who contradicted him. He kept a close watch over Bolsheviks and who among them were not able to fashion themselves up to his avenues were denounced to have outlived their usefulness.

Stalin is represented superficially through the character of No1(though not clearly mentioned) in the novel whose portrait stares from the walls of each house in the totalitarian state of Darkness at Noon. No1 who is characterised to be Machiavellian in nature is an omnipresent and omnipotent figure, his overwhelming presence throughout the novel forebode the atmosphere of doom.

The plot of the novel lies in Rubashov's evolving realisation of his guilt and his loss of belief in the infallible justice of communism that leads him to relinquish his powerful position in the party and acceptance of his grammatical fiction that he hitherto denied. Rubashov is imprisoned in the beginning of the novel for some unexplained crimes, though he had been dreaming about his impending imprisonment for long. Inside the prison cell, he goes on a psychological journey with his anguished self that alters his previous notions about the party's righteousness. While awaiting his interrogation and ultimate execution, hereminiscent about his life as he marches in the prison cell, rubbing his penc- nez, a habit he had developed over a long time. His entire life unfolds in his mind, he sees how he has served the party unfailingly in his long career as a devote member and a first-class revolutionary fulfilling all his duties to party without questioning, inside the country and on mission abroad. Rubashov approached things all his life,from the 
view point of pure logic. Like all the communist he believed that end justifies all the means. His unshaken believe in Communist ideology which puts Mankind before man and values man only to the extent as he is useful for the party. Individual is seen as a part of the mass and is receded to background to fulfil the greater good and is used as an instrument to realise the goal of utopia. It takes him enormous amount of self-interrogation to look beyond his rational, self- denying personality and to be able to detach himself from communist ideology, to find himself as a self-conscious individual realising the importance of grammatical fiction and to understand the causes for the failure of utopia.

The communists were blinded by the dream of socialist-classless society and ran amuck to it. The militant communist'sutter believe in the validity of maxim "end justifies all the means" resulted in violence and this violence was justified on the name of the greater good. Rubashov asserted and uplifted the need for sacrifice for the fulfilment of utopian dream and was himself responsible for the death of three people. The first character Rubashov sacrificed on the guiding of the party is, Richard. He is the leader of the communist party in an unnamed country (with all the characteristics of Germany). Richard is a loyal member of the party and tries to support its cause even after it has been quashed by Nazis. Richard knew that the party suffered some severe blows inside and outside the country but the official party line still emphasising on its strength, which is bound to fail. To brace up the party activitiesagain and to rejuvenate it he relies on his instincts rather than directions of party, thus causingtreason by party's standard and was consequently denounced and sacrificed by Rubashov on behalf of the guiding party logic. Rubashov acts on party's order unflinchingly without analysing the viciousness of the act and unmovedly announces his dismissal from the party and leaves him to be fed by Nazis.Later in the novel Rubashov's imprisonment by his own party forces him to acknowledge his pent-upconsciousness which makes him wonder whether Richard's sacrifice was even worth it.

Little Lowey, the local leader of dock workers of the party at Belgium portis yet another victim that Rubashov sacrifices for the cause of the party. Little Lowey is a fervent believer in communism, yet he is principled. He has been on many occasions let down party but his trust in the party does not waver. Little Lowey is one of the old guards who could not compromise their morality as par the changing demands of the new party. He does not accept the party's betrayal of its own decision of boycotting enemy ships and later establishing trade with them. He disobeys the order of allowing the enemy ships at the harbour and for that he is called agent provocateur. After this incidence Little Lowey gets disenchanted by the revolution and disappointed in his heroes of the war,he hangs himself after expressing his opinions about the wrong headedness of the new party.

The third character sacrificed by Rubashov was his secretary Arlova with whom he has a short lived but passionate affair. Arlova carried out Rubashov's orders that were against the party line for which she was accused of oppositional conspiracy and was executed. Rubashov could have saved her by accepting that he was responsible for the act but he gave himself the reason that his life was more valuable to the party than Arlova's. So third life betrayed by Rubashov was not for party's sake but for saving his own neck.

Though Rubashov after all three incidents was able to subside his feelings of guilt and give himself a rational excuse for his crimes but he has not been fully successful in doing so. He suffers from episodes of toothache each time he thinks about their deaths. It appears that his suppressed consciousness makes itself felt through toothache.

His confession was brought about by Rubashov's logical deduction on the instigation of Ivanov and physical unrest method used by Gletkin. Though Rubahsov can't be assumed guilty of treason when refereed by liberal standards but he knew he was guilty, he was guilty committing thought crime. A totalitarian Party demands unwavering devotion and when a man like Rubashov who served the party for 40 years, have had powerful position inside the party and executed all party's commands without any second considerations, entertains any discreet and reasonable thought about No1, suspects party's course of action, questions its moral values and adopts humanitarian attitude becomes an impediment to the pursuit of party's objectives is definitely guilty and needs to be annihilated. But it was difficult for party to dispose of a man of Rubashov's stature quietly so it was required of him to make public confession because his unexplained liquidation could have swayed public opinion. The task of obtaining the confession was handed over to other twoparty members Ivanov and Gletkin, Ivanov is an old militant whereas Gletkin is the product of new generation who does not know anything about the old revolutionaries and is oblivious the idea with which the party was conceived. Ivanov who was Rubashov's comrade understood the working of his mind and knows that he is a hardened militant and can't be broken under physical pressure so decides to bargain with him reasonably but he was later shot for dealing with him too sympathetically. Ivanov, in one of the hearings tells Rubashov that the reason because of which old revolutionaries perished was 
their moral dilettantism with which the Gletkin who are the product of consequence don't suffer, for these Gletkin, the principle that end justifies means is and remains, only political ethic. They work according to the rule of practical advantages rather than kindness and morality, for them human impulses are nothing but repellent debauchery. Morality is defined by the ultimate result and its path is twisted and turned to support their reign.

\section{CONCLUSION}

Koestler's purpose behind writing Darkness at Noon was not only to provide a critique of totalitarianism but also to criticise the Bolshevik philosophy which was antidemocratic, anti-humanitarian and illiberal. Their constant emphasis on centralization unavoidably led to dictatorship. Old Bolsheviks started Russian revolution with the promise of classless utopia but none of them foresaw the twisted roads and bewildering roads from where revolution was to go through. At that time communism seemed to be only alternative to fight Nazism, Fascism and to end capitalism. It attracted a number of youths to its honey coated ideologies and far -fetched goals. The party who initiated such a mass movement disintegrated after the death of Lenin. The contradiction for the rise in power between anti-soviet block of rightist and Trotskyist eventually led to the absurdities and the horror of great purge. After Trotsky's removal Stalin rose to power and henceforth party's main focus shifted from mass' welfare to party's welfare. Their objective was not to uplift and sustain the life of mass but to sustain itself. People were used as instrument to strengthen party's position. The only purpose Stalin had was to gain more and more power by hook or crook and it inscribed the chapters in the history of totalitarianism with violence. Stalin inhabited all unethical advices imbibed in Machiavelli's Prince but neither did Prince achieve its ends nor Stalin could reign forever. The abortive fate of prince and communism and the influence of so called utopian texts in reality dictates that it is the application of morality into politics which proves itself truly efficacious in long run.

\section{REFERENCES}

[1] Koestler, Arthur. Darkness at Noon. Translated by Daphne Hardy, Vintage U.K. Random House, 2005.

[2] Arendt, Hannah. The Origins of Totalitarianism. Harcourt Publishing Company. 1973.

[3] Ali, Mohammed Seid. "MORALITY AND POLITICS WITH REFERENCE TO MACHIAVELLI'S THE PRINCE” European Scientific Journal, vol.11, No.17, 2015, pp.

eujournal.org/index.php/esj/article/viewFile/5804/5619.

Accessed $20^{\text {th }}$ January 2018.
[4] "Darkness at Noon." Novels for Students. Encyclopedia.com, www. encyclopedia.com/arts/educational-magazines/darknessnoon. Accessed 23 January. 2018.

[5] Wallace, Sarah. "Assessing the Relationship between Power and Morality in Nonviolent Action". E-International Relations Students, E-IR, 05 January 2016, www.eir.info/2016/05/03/assessing-the-relationship-betweenpower-and-morality-in-nonviolent-action/. Accessed 27 January 2018.

[6] Harrison, Robert P., "What can you learn from Machiavelli?". Yale Insights, Yale School of Management, 01 January 2011, insights.som.yale.edu/insights/what-canyou-learn-machiavelli. Accessed 2 February 2018.

[7] "Darkness at Noon summary and study guide". Super Summary, www.supersummary.com/darkness-atnoon/summary/. Accessed 5Feburary 2018.

[8] "Niccolo Machiavelli". Wikipedia, the free encyclopedia, en.wikipedia.org/wiki/Niccolò_Machiavelli. Accessed 10 feburary.

[9] Strauss, Harold." The Riddle of Moscow's Trial". The New York Times On The Web, May 25 1941. archive. nytimes.com/www.nytimes.com/ books/00/01/02/ specials/ koestler-darkness.html. 